The University of Maine

\title{
DigitalCommons@UMaine
}

Earth Science Faculty Scholarship

Earth Sciences

7-29-2006

\section{Ice Core Evidence for a Second Volcanic Eruption Around 1809 in the Northern Hemisphere}

Kaplan Yalcin

Cameron P. Wake

Karl J. Kreutz

University of Maine - Main, karl.kreutz@maine.edu

Mark S. Germani

Sallie I. Whitlow

Follow this and additional works at: https://digitalcommons.library.umaine.edu/ers_facpub

Part of the Earth Sciences Commons

\section{Repository Citation}

Yalcin, Kaplan; Wake, Cameron P.; Kreutz, Karl J.; Germani, Mark S.; and Whitlow, Sallie I., "Ice Core Evidence for a Second Volcanic Eruption Around 1809 in the Northern Hemisphere" (2006). Earth Science Faculty Scholarship. 44.

https://digitalcommons.library.umaine.edu/ers_facpub/44 


\title{
Ice core evidence for a second volcanic eruption around 1809 in the Northern Hemisphere
}

\author{
Kaplan Yalcin, ${ }^{1,2}$ Cameron P. Wake, ${ }^{1}$ Karl J. Kreutz, ${ }^{3}$ Mark S. Germani, ${ }^{4}$ \\ and Sallie I. Whitlow ${ }^{1}$ \\ Received 9 February 2006; revised 10 April 2006; accepted 14 June 2006; published 29 July 2006.
}

[1] A volcanic signal observed in ice cores from both polar regions six years prior to Tambora is attributed to an unknown tropical eruption in 1809. Recovery of dacitic tephra from the 1809 horizon in a Yukon ice core (Eclipse) that is chemically distinct from andesitic 1809 tephra found in Antarctic ice cores indicates a second eruption in the Northern Hemisphere at this time. Together with the similar magnitude and timing of the 1809 volcanic signal in the Arctic and Antarctic, this could suggest a large tropical eruption produced the sulfate and Antarctic tephra and a minor Northern Hemisphere eruption produced the Eclipse tephra. Nonetheless, the possibility that there were coincidental eruptions of similar magnitude in both hemispheres, rather than a single tropical eruption, should not be discounted. Correctly attributing the source of the 1809 volcanic signal has important implications for modeling the magnitude and latitudinal distribution of volcanic radiative forcing. Citation: Yalcin, K., C. P. Wake, K. J. Kreutz, M. S. Germani, and S. I. Whitlow (2006), Ice core evidence for a second volcanic eruption around 1809 in the Northern Hemisphere, Geophys. Res. Lett., 33, L14706, doi:10.1029/2006GL026013.

\section{Introduction}

[2] Explosive volcanic eruptions in the tropical latitudes can perturb climate on a global scale; unfortunately an incomplete record of volcanism complicates investigations of the influence of such eruptions on past climate. Large eruptions of global influence may have gone unnoticed as recently as the 1809 eruption known only in ice core records from Greenland [Cole-Dai et al., 1991; Zielinski, 1995; Langway et al., 1995; Clausen et al., 1997; Kohno and Fujii, 2002] and Antarctica [Legrand and Delmas, 1987; Cole-Dai et al., 1991, 1997, 2000; Moore et al., 1991; Delmas et al., 1992; Langway et al., 1995; Stenni et al., 1999; Palmer et al., 2002]. Assuming a tropical source of the eruption, Zielinski [1995] calculated a stratospheric $\mathrm{H}_{2} \mathrm{SO}_{4}$ loading of 34 to $68 \times 10^{12} \mathrm{~g}$ and an optical depth of 0.11 to 0.28 from the GISP2 ice core, placing the 1809 eruption among the largest of the last few centuries.

\footnotetext{
${ }^{1}$ Climate Change Research Center, Institute for the Study of Earth, Oceans, and Space University of New Hampshire, Durham, New Hampshire, USA.

${ }^{2}$ Now at Department of Geosciences, Oregon State University, Corvallis, Oregon, USA.

${ }^{3}$ Climate Change Institute and Department of Earth Sciences, University of Maine, Orono, Maine, USA.

${ }^{4}$ MicroMaterials Research, Inc., Burr Ridge, Illinois, USA.
}

A latitude between $20^{\circ} \mathrm{N}$ and $10^{\circ} \mathrm{S}$ and an eruption column height of at least $25 \mathrm{~km}$ (Volcanic Explosivity Index (VEI) 5 or greater) are requirements for a volcanic signal to be seen in both Greenland and Antarctica [Kohno and Fujii, 2002]. However, no eruption with a VEI $>3$ is reported in the historical volcanism record between 1801 and 1812 [Simkin and Siebert, 1994].

[3] Analysis of tephra associated with volcanic $\mathrm{SO}_{4}^{2-}$ peaks in ice cores can provide information on the source volcano responsible for an eruption. Tephra associated with the $1809 \mathrm{SO}_{4}^{2-}$ peak has been found in ice cores from South Pole [Palais et al., 1990] and Dome C, Antarctica (De Angelis et al. [1985]; reinterpreted to be from the 1809 horizon by Legrand and Delmas [1987]) (Figure 1). Palais et al. [1990] suggested the source of the tephra found in the South Pole and Dome $\mathrm{C}$ ice cores was Cosiguina, Nicaragua, based on the similar chemical compositions of the Antarctic 1809 tephra and Cosiguina 1835 eruption products and a March 1809 eruption date for Cosiguina [Simkin and Siebert, 1994]. However, recent work on Cosiguina has not uncovered any geologic evidence for an eruption around 1809 [Scott et al., 2006] and the 1809 eruption date for Cosiguina is now regarded as spurious (S. Self, personal communication, 2004).

[4] In this paper we present evidence for a second eruption in the Northern Hemisphere in 1809 using tephra found in an ice core from Eclipse Icefield. The $\mathrm{SO}_{4}^{2-}$ contribution from this eruption to the 1809 volcanic signal in circum-Arctic ice cores is examined to assess the significance of this eruption. We conclude by discussing the

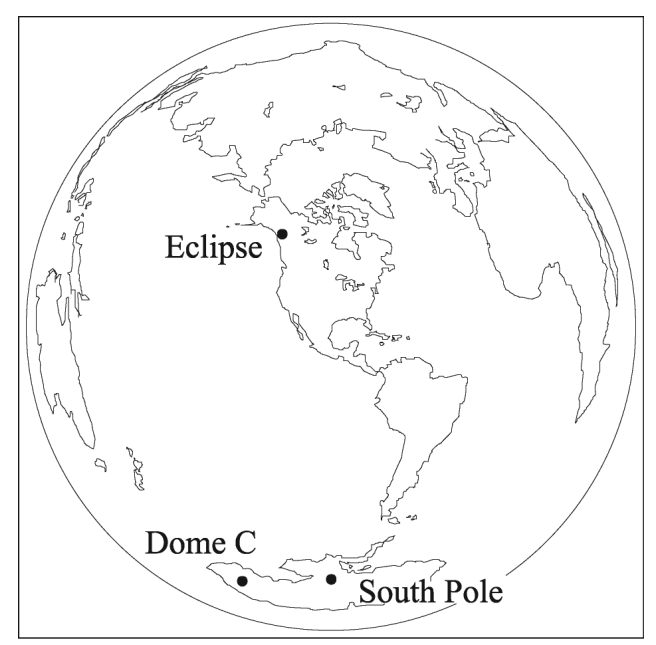

Figure 1. Location of the Eclipse, Dome C, and South Pole ice cores. 


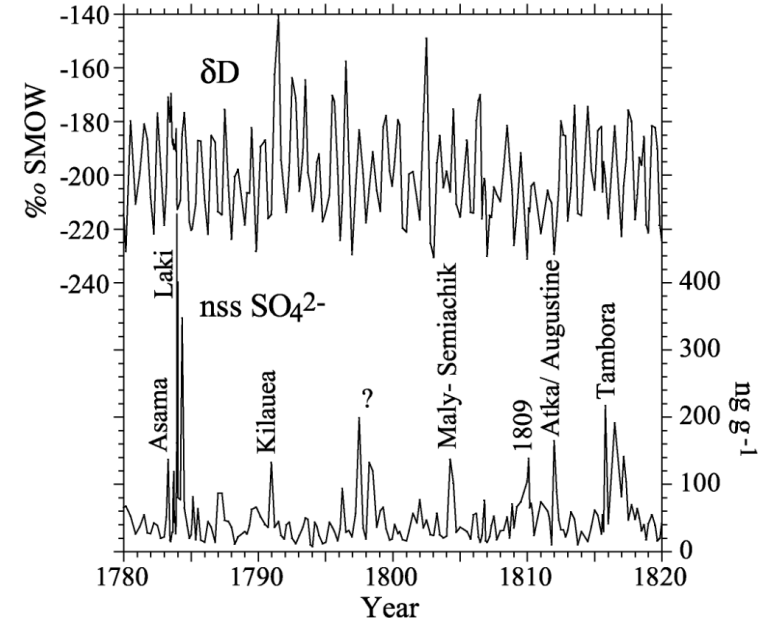

Figure 2. The $\delta \mathrm{D}$ (top) and non-sea-salt $\mathrm{SO}_{4}{ }^{2-}$ (bottom) records from the Eclipse ice core for the period 1780 to 1820. Possible sources of volcanic $\mathrm{SO}_{4}{ }^{2-}$ signals are indicated.

implications of these results in attributing the source of the 1809 volcanic signal.

\section{Collection and Analysis of $\mathbf{1 8 0 9}$ Tephra From the Eclipse Ice Core}

[5] The strongest evidence for a tropical location of the unknown 1809 eruption would come from identification of volcanic glass shards of similar composition associated with the 1809 horizon in both Arctic and Antarctic ice cores. However, no analyses of 1809 tephra have been previously reported from Arctic ice cores (including Greenland). Here we present the major oxide composition of tephra found in the 1809 horizon in a $345 \mathrm{~m}$ ice core from Eclipse Icefield (Yukon) drilled in 2002 [Yalcin et al., 2006]. This core was analyzed as described for the 1996 Eclipse ice core [Yalcin et al., 2003] and the 1809 horizon dated by annual layer counting with age control provided by identification of the Laki 1783 and Tambora 1815 volcanic sulfate horizons (Figure 2). Tephra was collected by filtering core melt water through a 0.2 -micron polycarbonate membrane (no tephra layer was visible in the core). Individual particles greater than four micrometers with glass shard morphology were analyzed for major oxide composition using a Hitachi S-570 scanning electron microscope.

[6] Tephra from the 1809 horizon in the Eclipse ice core has a chemical composition that is distinctly different from 1809 tephra found in the South Pole and Dome C ice cores (Table 1). Following the total alkali-silica classification scheme [LeBas et al., 1986], tephra from the South Pole and Dome $\mathrm{C}$ ice cores is andesitic to trachyandesitic, while the Eclipse tephra is trachytic in composition (Figure 3). A Student's t-test can be used to evaluate the significance of the

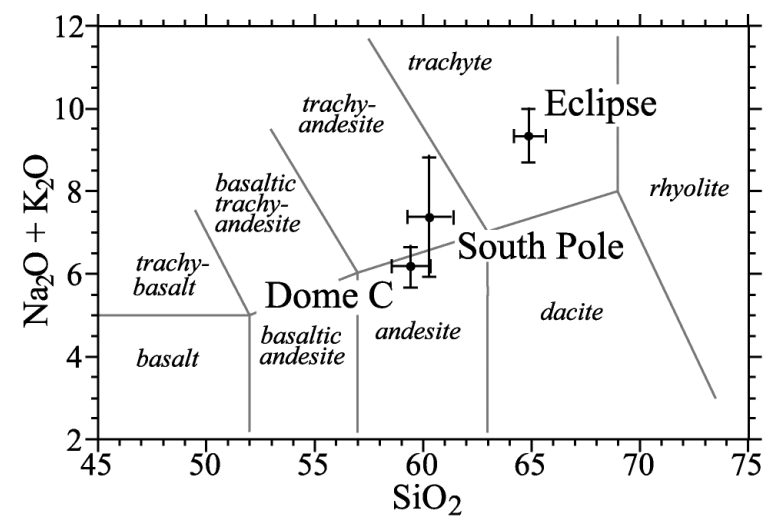

Figure 3. Chemical classification of 1809 ice core tephras using a total alkali $\left(\mathrm{Na}_{2} \mathrm{O}+\mathrm{K}_{2} \mathrm{O}\right)$ versus silica variation diagram. Error bars represent the $95 \%$ confidence interval estimated from the standard error and observed mean of each tephra set.

compositional differences between the Eclipse, South Pole, and Dome C tephras [Keenan, 2003]. The t-test can only be applied for those constituents whose mean divided by standard deviation is greater than 2.5 in both data sets to be compared so that the assumption of a normal distribution is satisfied. For constituents satisfying this assumption, the difference between the Eclipse/South Pole tephras and Eclipse/Dome $C$ tephras is significant at the $99.9 \%$ confidence level, except for $\mathrm{Al}_{2} \mathrm{O}_{3}$ (Table 2). Conversely, the t-test detects no significant difference between the South Pole and Dome $\mathrm{C}$ tephras, except for $\mathrm{TiO}_{2}$ at the $90 \%$ confidence level. These results demonstrate that the South Pole and Dome C tephras are from the same volcano while the Eclipse tephra is from a different volcano, implying a second eruption around 1809 as the source of the Eclipse tephra.

[7] All identified tephras from the Eclipse ice cores are from high northern latitude volcanoes (Alaska, Kamchatka, or Iceland [Yalcin et al., 2003]). The only volcano in the region known to have been active around 1809 is Bogoslof in the Aleutians, but its products range from basaltic to andesitic in composition [Miller et al., 1998]. Though no eruption is reported around 1809, Aniakchak, Shishaldin, and Okmok volcanoes in Alaska erupt material similar in composition to the Eclipse 1809 tephra [Miller et al., 1998], as do some Kamchatkan volcanoes. Although identifying the volcano which produced the Eclipse 1809 tephra is not possible with the available data, the most likely source is a high northern latitude eruption that had a negligible global climate impact.

\section{Magnitude of the 1809 Signal From Sulfate Flux Calculations}

[8] The eruption responsible for the 1809 tephra at Eclipse, depending on its magnitude, may or may not be a

Table 1. Major Oxide Composition of 1809 Ice Core Tephras ${ }^{\mathrm{a}}$

\begin{tabular}{lcccccccccc}
\hline \multicolumn{1}{c}{ Sample } & $\mathrm{SiO}_{2}$ & $\mathrm{TiO}_{2}$ & $\mathrm{Al}_{2} \mathrm{O}_{3}$ & $\mathrm{FeO}$ & $\mathrm{MgO}$ & $\mathrm{CaO}$ & $\mathrm{Na}_{2} \mathrm{O}$ & $\mathrm{K}_{2} \mathrm{O}$ & $\mathrm{n}$ & $\mathrm{Reference}$ \\
\hline 1809 Eclipse & $64.86(1.10)$ & $1.15(0.20)$ & $16.13(0.66)$ & $3.84(0.71)$ & $1.12(0.49)$ & $3.56(0.73)$ & $6.64(0.77)$ & $2.70(0.26)$ & 10 this work \\
1809 South Pole & $60.28(1.41)$ & $0.84(0.16)$ & $15.80(1.77)$ & $7.91(1.86)$ & $2.35(0.93)$ & $5.45(0.92)$ & $4.26(0.75)$ & $3.11(1.38)$ & 8 & Palais et al. $[1990]$ \\
1809 Dome C & $59.44(1.63)$ & $0.67(0.24)$ & $16.43(0.51)$ & $9.00(0.72)$ & $2.83(0.73)$ & $5.44(0.82)$ & $4.14(0.52)$ & $2.05(0.40)$ & 13 & De Angelis et al. [1985] \\
\hline
\end{tabular}

${ }^{\mathrm{a}}$ Compositions given as weight $\%$, recalculated to a sum of $100 \%$, where $\mathrm{n}$ is the number of individual tephra particles analyzed. Values are means for the specified number of particles, with the standard deviation in parentheses. 
Table 2. Calculated t Statistics and Significance Levels for Comparisons of 1809 Ice Core Tephras ${ }^{\mathrm{a}}$

\begin{tabular}{|c|c|c|c|c|c|c|c|c|c|}
\hline Sample Sets & df & $\mathrm{SiO}_{2}$ & $\mathrm{TiO}_{2}$ & $\mathrm{Al}_{2} \mathrm{O}_{3}$ & $\mathrm{FeO}$ & $\mathrm{MgO}$ & $\mathrm{CaO}$ & $\mathrm{Na}_{2} \mathrm{O}$ & $\mathrm{K}_{2} \mathrm{O}$ \\
\hline Eclipse 1809 - SP1809 & 16 & 7.51 & 3.64 & 0.50 & 5.87 & n.a. & 4.74 & 6.62 & n.a. \\
\hline Probability < & & 0.001 & 0.01 & & 0.001 & & 0.001 & 0.001 & \\
\hline Eclipse 1809 - Dome C 1809 & 21 & 9.48 & 5.21 & 1.17 & 17.18 & n.a. & 5.80 & 8.80 & 4.74 \\
\hline Probability < & & 0.001 & 0.001 & & 0.001 & & 0.001 & 0.001 & 0.001 \\
\hline $\begin{array}{l}\text { SP } 1809 \text { - Dome C } 1809 \\
\text { Probability < }\end{array}$ & 19 & 1.24 & $\begin{array}{c}1.91 \\
0.1\end{array}$ & 0.98 & 1.59 & 1.24 & 0.02 & 0.39 & n.a. \\
\hline
\end{tabular}

${ }^{a}$ Where df indicates the degrees of freedom and n.a. denotes that the assumption of normal distribution is not satisfied. Probability levels are the chance the sample sets would have observed values so different if they were from the same population.

significant contributor to the 1809 volcanic $\mathrm{SO}_{4}^{2-}$ signal in Arctic ice cores. We investigated this by calculating the $\mathrm{SO}_{4}^{2-}$ flux for the 1809 eruption at Eclipse and compared our results to those calculated from other ice cores. To separate volcanic $\mathrm{SO}_{4}^{2-}$ from other $\mathrm{SO}_{4}^{2-}$ sources, we used an empirical orthogonal function (EOF) decomposition to describe the variance in the Eclipse glaciochemical data set. Applying EOF analysis to the suite of ions measured in the Eclipse ice core (excluding $\mathrm{NH}_{4}^{+}$) reveals that EOF 5 is loaded solely with $\mathrm{SO}_{4}^{2-}$ and describes $5.3 \%$ of the total variance in the dataset, but $20.3 \%$ of the variance in the $\mathrm{SO}_{4}^{2-}$ time series. Volcanic eruptions have been identified as the source of this $\mathrm{SO}_{4}^{2-}$ [Yalcin et al., 2003]. Total $\mathrm{SO}_{4}^{2-}$ deposition, or flux, for the 1809 event was calculated as the product of the volcanic $\mathrm{SO}_{4}^{2-}$ concentration and the water equivalent length of the sample (corrected for layer thinning), summed for the samples containing fallout attributable to the event. For comparison with other ice core sites where different mass transfer mechanisms (wet and dry deposition, riming) may vary in importance, we calculated the volcanic $\mathrm{SO}_{4}^{2-}$ flux ratio of the 1809 eruption relative to Tambora [Cole-Dai et al., 1997].

[9] The volcanic $\mathrm{SO}_{4}^{2-}$ flux from the unknown 1809 and Tambora eruptions at Eclipse was 3.69 and $7.08 \mu \mathrm{g} \mathrm{cm}^{-2}$, respectively. The volcanic flux from the 1809 event at Eclipse, 54\% of Tambora, is in good agreement with results from both Greenland (60-78\%) and Antarctica (26-60\%) (Table 3). This result suggests little additional $\mathrm{SO}_{4}^{2-}$ deposition at Eclipse from the eruption whose tephra we recovered, assuming the sulfate fallout in Greenland is from a tropical eruption. Because no tephrochronological evidence exists to link the 1809 fallout in Greenland ice cores to a tropical eruption, the high northern latitude eruption whose tephra we recovered at Eclipse could also be the source of the volcanic sulfate in Greenland.

\section{Implications of These Results}

[10] The existence of a second eruption in the Northern Hemisphere around 1809 raises the possibility that the bipolar 1809 volcanic signal was the result of coincidental eruptions in the high latitudes of both hemispheres, rather than a tropical eruption that was dispersed to both hemispheres. There are three lines of evidence that suggest a tropical eruption affected both hemispheres in 1809. First, the 1809 signal has a similar magnitude in both hemispheres [Cole-Dai et al., 1991]. Second, there is a close match in the timing of the 1809 event in both Greenland and Antarctic cores [Cole-Dai et al., 1997]. Third, there is both instrumental [Chenoweth, 2001] and proxy [Crowley et al., 1997] evidence of short-term cooling in the tropics in 1809 and 1810. If these temperature anomalies are volcanic in origin, they suggest a tropical eruption because aerosols from even the largest high latitude eruptions do not reach the tropics.

[11] Our results demonstrate that there were at least two separate volcanic eruptions around 1809. If the Antarctic tephra is also from a high-latitude volcano (but in the Southern Hemisphere), a large tropical eruption is not needed to explain the bipolar volcanic signal. Instead, there could have been volcanic eruptions in the high latitudes of both hemispheres, similar in timing and magnitude, which produced the observed volcanic sulfate deposition in Greenland and Antarctica. This hypothesis could explain why a source volcano has not been identified. First, the eruptions would not need to be as large to account for the observed sulfate deposition if they occurred in the high latitudes. Second, the eruptions could have taken place in comparatively more remote regions at higher latitudes were they went unobserved or unreported.

[12] At present, the available data does not permit unequivocal distinction between these competing scenarios. However, the magnitude and latitudinal distribution of radiative forcing resulting from a large tropical eruption would be very different from that resulting from coincidental high latitude eruptions. For this reason, paleoclimate models for the early 1800 's that assume a single 1809 eruption in the tropics and global dispersal may not be simulating the correct volcanic radiative forcing. The pos-

Table 3. Ice Core Volcanic Sulfate Fluxes $\left(\mathrm{ug} \mathrm{cm}^{-2}\right.$ ) From the 1809 Eruption Relative to Tambora ${ }^{a}$

\begin{tabular}{|c|c|c|c|c|}
\hline Site & $\mathrm{fV}$ & $\mathrm{fT}$ & $\mathrm{fV} / \mathrm{fT}$ & Reference \\
\hline \multicolumn{5}{|c|}{ Yukon } \\
\hline Eclipse & 3.7 & 7.1 & 0.52 & this work \\
\hline \multicolumn{5}{|c|}{ Greenland } \\
\hline Site $\mathrm{T}$ & 2.8 & 4.7 & 0.60 & Cole-Dai et al. [1991] \\
\hline GRIP & 2.5 & 3.5 & 0.71 & Clausen et al. [1997] \\
\hline GISP2 & 2.8 & 3.6 & 0.78 & Zielinski [1995] \\
\hline \multicolumn{5}{|c|}{ Antarctica } \\
\hline Dome $\mathrm{C}$ & 1.0 & 3.9 & 0.26 & Castellano et al. [2005] \\
\hline Plateau Remote & 0.8 & 2.2 & 0.37 & Cole-Dai et al. [2000] \\
\hline Siple (2) & 5.4 & 13.3 & 0.40 & Cole-Dai et al. [1997] \\
\hline Siple (1) & 5.3 & 12.9 & 0.41 & Cole-Dai et al. [1991] \\
\hline South Pole (1) & 3.0 & 7.2 & 0.41 & Delmas et al. [1992] \\
\hline Hercules Neve & 0.7 & 1.7 & 0.45 & Stenni et al. [1999] \\
\hline South Pole (2) & 3.2 & 6.8 & 0.47 & Delmas et al. [1992] \\
\hline Law Dome & 4.5 & 8.0 & 0.56 & Palmer et al. [2002] \\
\hline Dyer & 5.4 & 9.0 & 0.60 & Cole-Dai et al. [1997] \\
\hline
\end{tabular}

${ }^{\mathrm{a}}$ Where $\mathrm{fV}$ is the volcanic sulfate flux attributable to the 1809 eruption, $\mathrm{fT}$ is the flux from Tambora, and $\mathrm{fV} / \mathrm{fT}$ is the flux ratio of the 1809 eruption to the Tambora eruption in the same core. For Siple and South Pole, multiple cores are available. 
sibility also exists that coincidental eruptions in the high latitudes of both hemispheres in the more distant past produced volcanic signals in both polar regions that are incorrectly inferred to be tropical in origin. Only through tephrochronological evidence can a common source in the tropics be definitively established.

[13] Acknowledgments. We thank W. Scott and S. Self for insights concerning eruptive activity at Cosiguina prior to 1835 , M. Twickler for the map projection used in Figure 1, and J. Palais, J. Johnson, and an anonymous reviewer for helpful comments that resulted in an improved manuscript. The National Science Foundation Office of Polar Programs funded this research.

\section{References}

Castellano, E., S. Becagli, M. Hansson, M. Hutterli, J. R. Petit, M. R. Rampino, M. Severi, J. P. Steffensen, R. Traversi, and R. Udisti (2005), Holocene volcanic history as recorded in the sulfate stratigraphy of the European Project for Ice Coring in Antarctica Dome C (EDC96) ice core, J. Geophys. Res., 110, D06114, doi:10.1029/2004JD005259.

Chenoweth, M. (2001), Two major volcanic cooling episodes derived from global marine air temperature, AD 1807-1827, Geophys. Res. Lett., 28, 2963-2966.

Clausen, H. B., C. U. Hammer, C. S. Hvidberg, D. Dahl-Jensen, J. P. Steffensen, J. Kipfstuhl, and M. Legrand (1997), A comparison of the volcanic records over the past 4000 years from the Greenland Ice Core Project and Dye 3 Greenland ice cores, J. Geophys. Res., 102, 26,707$26,723$.

Cole-Dai, J., E. Mosley-Thompson, and L. Thompson (1991), Ice core evidence for an explosive tropical eruption 6 years preceding Tambora, J. Geophys. Res., 96, 17,361-17,366.

Cole-Dai, J., E. Mosley-Thompson, and L. Thompson (1997), Annually resolved Southern Hemisphere volcanic history from two Antarctic ice cores, J. Geophys. Res., 102, 16,761-16,771.

Cole-Dai, J., E. Mosley-Thompson, S. Wight, and L. Thompson (2000), A 4100-year record of explosive volcanism from an East Antarctic ice core, J. Geophys. Res., 105, 24,431-24,441.

Crowley, T. J., T. R. Quinn, F. W. Taylor, C. Henin, and P. Joannot (1997), Evidence for a volcanic cooling signal in a 335-year coral record from New Caledonia, Paleoceanography, 12, 633-639.

De Angelis, M., L. Fehrenbach, C. Jehanno, and M. Maurette (1985), Micrometer-sized volcanic glasses in polar ice and snows, Nature, 317, $52-54$.

Delmas, R. J., S. Kirchner, J. M. Palais, and J. R. Petit (1992), 1000 years of explosive volcanism recorded at the South Pole, Tellus, 44, 335-350.

Keenan, D. J. (2003), Volcanic ash retrieved from the GRIP ice core is not from Thera, Geochem. Geophys. Geosyst., 4(11), 1097, doi:10.1029/ 2003GC000608.

Kohno, M., and Y. Fujii (2002), Past 220-year bipolar volcanic signals: remarks on common features of their source eruptions, Ann. Glaciol. $35,217-223$.
Langway, C. C., K. Osada, H. B. Clausen, C. U. Hammer, and H. Shoji (1995), A 10-century comparison of prominent bipolar volcanic events in ice cores, J. Geophys. Res., 100, 16,241-16,247.

LeBas, M. J., R. W. Maitre, A. Strickeisen, and B. Zanettin (1986), A chemical classification of volcanic rocks based on the total alkali-silica diagram, J. Petrol., 27, 745-750.

Legrand, M., and R. J. Delmas (1987), A 220 year continuous record of volcanic $\mathrm{H}_{2} \mathrm{SO}_{4}$ in the Antarctic ice sheet, Nature, 327, 671-676.

Miller, T. P., R. G. McGimsey, D. H. Richter, J. R. Riehle, C. J. Nye, M. E. Yount, and J. A. Dumoulin (1998), Catalog of the historically active volcanoes of Alaska, U.S. Geol. Surv. Open File Rep., 98-582, 104 pp.

Moore, J. C., H. Narita, and N. Maeno (1991), A continuous 770-year record of volcanic activity from East Antarctica, J. Geophys. Res., 96, $17,353-17,359$

Palais, J. M., S. Kirchner, and R. J. Delmas (1990), Identification of some global volcanic horizons by major element analysis of fine ash in Antarctic ice, Ann. Glaciol., 14, 216-220.

Palmer, A. S., V. I. Morgan, M. A. J. Curran, T. D. Van Ommen, and P. A. Mayewski (2002), Antarctic volcanic flux rations from Law Dome ice cores, Ann. Glaciol., 35, 329-332.

Scott, W., C. Gardner, G. Devoli, and A. Alvarez (2006), The A.D. 1835 eruption of Volcán Cosiguina, Nicaragua: A guide for assessing local volcanic hazards, in Volcanic Hazards in Central America, edited by W. I. Rose et al., Spec. Pap. Geol. Soc. Am., in press.

Simkin, T., and L. Siebert (1994), Volcanoes of the World, Geosci. Press, Tucson, Ariz.

Stenni, B., R. Caprioli, L. Cimmino, C. Cremisini, O. Flora, R. Gragnani, A. Longinelli, V. Maggi, and S. Torcini (1999), 200 years of isotope and chemical records in a firn core from Hercules Neve, northern Victoria Land, Antarctica, Ann. Glaciol., 29, 106-112.

Yalcin, K., C. P. Wake, and M. Germani (2003), A 100-year record of North Pacific volcanism in an ice core from Eclipse Icefield, Yukon, Canada, J. Geophys. Res., 108(D1), 4012, doi:10.1029/2002JD002449.

Yalcin, K., C. P. Wake, S. Whitlow, and K. Kreutz (2006), A 1000-year record of forest fire activity from Eclipse Icefield, Yukon, Canada, Holocene, 16, 200-209.

Zielinski, G. A. (1995), Stratospheric loading and optical depth estimates of explosive volcanism over the last 2100 years derived from the GISP2 Greenland ice core, J. Geophys. Res., 100, 20,937-20,955.

M. S. Germani, MicroMaterials Research, Inc., 136 Shore Drive, Suite 200, Burr Ridge, IL 60527, USA. (mgermani@micromaterialsresearch. com)

K. J. Kreutz, Climate Change Institute and Department of Earth Sciences, University of Maine, Orono, ME 04469, USA. (karl.kreutz@maine.edu)

C. P. Wake and S. I. Whitlow, Climate Change Research Center, Institute for the Study of Earth, Oceans, and Space University of New Hampshire, Durham, NH 03824, USA. (cameron.wake@unh.edu; siw@unh.edu)

K. Yalcin, Department of Geosciences, Oregon State University, Wilkinson Hall, Corvallis, OR 97331 USA. (yalcink@geo.oregonstate.edu) 